Chapman University

Chapman University Digital Commons

Communication Faculty Articles and Research

School of Communication

$12-14-2015$

\title{
The Relationship Between Elevation, Connectedness, and Compassionate Love in Meaningful Films
}

Sophie Janicke

Chapman University, janicke@chapman.edu

Mary Beth Oliver

Pennsylvania State University

Follow this and additional works at: http://digitalcommons.chapman.edu/comm_articles

Part of the Communication Technology and New Media Commons, Other Communication Commons, Other Film and Media Studies Commons, Other Psychology Commons, Social Psychology Commons, and the Theory and Philosophy Commons

\section{Recommended Citation}

Janicke, S. H. \& Oliver, M. B. (2015). Meaningful films: The relationship between elevation, connectedness and compassionate love. Journal of Psychology of Popular Media Culture. http://dx.doi.org/10.1037/ppm0000105

This Article is brought to you for free and open access by the School of Communication at Chapman University Digital Commons. It has been accepted for inclusion in Communication Faculty Articles and Research by an authorized administrator of Chapman University Digital Commons. For more

information, please contact laughtin@chapman.edu. 


\title{
The Relationship Between Elevation, Connectedness, and Compassionate Love in Meaningful Films
}

\author{
Comments \\ This is a pre-copy-editing, author-produced PDF of an article accepted for publication in journal, volume, in \\ year following peer review. The definitive publisher-authenticated version is available online at DOI: 10.1037/ \\ ppm0000105. This article may not exactly replicate the final version published in the APA journal. It is not the \\ copy of record.
}

\section{Copyright}

American Psychological Association 


\title{
The Relationship Between Elevation, Connectedness and Compassionate Love in Meaningful Films
}

\begin{abstract}
Expanding on the research of meaningful entertainment media and its effects, this study investigated the relationship between experiences related to elevation responses to film. Whereas research thus far has focused primarily on portrayals of altruism to elicit elevation, the results of this study show that portrayals of connectedness, love, and kindness in meaningful films are also able to elicit feelings of elevation. Moreover, elevation mediated the relationship between meaningful films and feelings of connectedness towards the transcendent, close others and toward one’s family; compassionate love towards close others; and compassionate motivation to love and be good to humanity. The study demonstrates the potential of meaningful films to increase experiences of connectedness to the transcendent, which ultimately can enhance our concern about the well-being of others, and motivation to be more compassionate even to strangers. Implications for the scholarship of positive media psychology are discussed.
\end{abstract}

Keywords: elevation, connectedness, transcendent experiences, compassionate love, meaningful film 


\section{The Relationship Between Elevation, Connectedness and Compassionate Love in Meaningful Films}

Traditionally, entertainment experiences have been conceptualized as hedonic experiences including pleasure, enjoyment, fun, relaxation, stimulation, and diversion (e.g., Bosshart \& Macconi, 1998; Vorderer, 2001; Vorder, Klimmt, \& Ritterfeld, 2004). However, describing the entertainment experience of tragic, dramatic, and moving films in simple hedonic terms has been shown problematic (Oliver, 1993). Thus, in recent years, media psychologists have expanded on the definition of hedonic enjoyment to explain the experiences and effects from particularly moving and meaningful narratives. For example, Vorderer (2001) acknowledged that entertaining content can lead to selfenhancement or self-realization, and Bartsch (2012) showed that a variety of media gratifications could be understood from the standpoint of eudaimonic well-being. Likewise, other researchers have reported that tragedy-induced sadness can instigate life reflection and thoughts regarding close relationships, which in turn serves to enhance feelings of life happiness (Knobloch-Westerwick, Gong, Hagner \& Kerbeykian, 2013). Moreover, theories of eudaimonia (Oliver \& Bartsch, 2010, 2011; Oliver \& Hartmann, 2010; Oliver \& Raney, 2011; see also Garland, Frederickson, Kring, Johnson, Meyer, \& Penn, 2010), terror management (Klimmt, 2011, Hofer, 2013), and moral foundation theory (Eden, Hartmann, Oliver and Mares, 2013; Oliver, Hoewe, Kim, Shade \& Bailey, 2014; Lewis, Tamborini \& Weber 2014) have been applied to understand how media experiences can lead to appreciation, meaningfulness (often referred to as elevation), insight into the human existence, as well as prosocial behaviors and altruistic motivations (Oliver, Hartmann, \& Woolley, 2012). In short, scholars are now devoting increased 
attention to understanding how media content, particularly film, can inspire viewers to be better people and to reflect on the human condition (see also, Wirth, Hofer, \& Schramm, 2012). However, many avenues are still unexplored with regards to how media can inspire and what factors lead to altruistic motivation. In an effort to expand upon extant scholarship on elevation (i.e., meaningful affect), the goal of this research was to investigate other self-transcendent experiences, specifically connectedness and compassionate love that inspire viewers to be more kind to fellow human beings.

\section{Self-Transcendent Emotions}

Emotions that are captured under the theories of eudaimonic well-being (Garland, et al., 2010; also see Baumeister, Vohs, Aaker \& Garbinsky, 2013 for a recent discussion on eudaimonic and hedonic happiness), which are those that foster the understanding about one's potential, meaning and purpose in life (i.e., Kashdan, Biswas-Diener, \& King, 2008; Oliver \& Raney, 2011), can also be described as transcendent emotions. The latter are different from hedonic, positive emotions in that they do not concern the self or goals of the self, but a loss of ego and an enhanced openness to others (Algoe \& Haidt, 2009; Haidt \& Keltner, 2004; Keltner \& Haidt, 2003; Schindler, Zink, Windrich, \& Menninghaus, 2013). The emotions of awe, elevation, gratitude, and admiration have been referred to as moral or self-transcendent emotions (cf. Algoe \& Haidt, 2009; Haidt, 2003; Haidt \& Morris, 2009; Keltner \& Haidt, 2003). Consistent with this label, scholars typically characterize self-transcendent emotions as those that are other oriented, that draw people out of their usual state of consciousness (Haidt \& Morris, 2009), and that motivate individuals to be better - that is, to engage in behaviors for the betterment of the self or for humanity (Haidt, 2003a; Algoe \& Haidt, 2009). Research has identified 
multiple situations and circumstances that help people to experience those selftranscendent emotions (i.e., being in nature, together with close others, expressing ones gratitude, being in a state of flow). However, it is only recently that researchers have started to systematically investigate media as a stimulus that can elicit this specific type of affect. Specifically, some scholars have started to explore the emotion of elevation as a response to meaningful entertainment (see Oliver et al., 2012). Oliver and her colleagues have argued that elevation as one of the other-praising, self-transcendent emotions is particularly relevant for meaningful entertainment, as such content often portrays moral virtues such as altruism, gratitude, charity, or generosity. According to Haidt and his collaborators (Algoe \& Haidt, 2009; Diessner, Iyer, Smith \& Haidt, 2013; Haidt, 2003b; Keltner \& Haidt, 2003) elevation (i.e., feelings of being moved, tender, touched, and inspired) is elicited when witnessing such acts of moral beauty, and when experienced, motivates individuals to emulate the virtuous behaviors. Elevation has been further conceptualized with mixed affective states (i.e., feeling sad and happy at the same time) and unique physiological responses such as goose bumps, a lump in the throat, and an opening of the chest (see Oliver et al., 2012).

So far research has concentrated on altruism as an elicitor of elevation. The goal of the present study was to examine if additional types of portrayals may also enhance elevation responses. Specifically, the present study investigated how witnessing human kindness, love, and connectedness as portrayals of moral beauty can elicit elevation and related eudaimonic experiences of connectedness and compassion.

\section{Portrayals of Moral Virtue and Connectedness in Entertainment}


Recent research on issues of morality has started to systematically investigate specific domains of morality (e.g., care, fairness, loyalty, purity, authority) that are associated with eliciting elevation (see Haidt \& Joseph, 2004). For example, Diessner, Solom, Frost, Parson, and Davidson (2008) found that engagement with moral beauty was most strongly correlated with the care domain from the Moral Foundations Theory (cf. MFT, Haidt \& Joseph, 2004). Likewise, Eden et al. (2013) found that videos portraying the moral domain of care elicited feelings of elevation, particularly for those individuals for whom the care domain was salient, which in turn impacted individuals' intentions to act prosocially. Expanding on these findings, Oliver et al. (2014) demonstrated that videos depicting the domains care and loyalty (put not purity) elicited elevation which mediated the effects of the videos on individual's feelings of connectedness to all humanity.

Related research has investigated meaningful versus purely pleasurable entertainment content on a more descriptive level. When asking participants about their perception of meaningful movies compared to pleasurable movies, Oliver and Hartmann (2010) found themes related to human connectedness to be highly prevalent, including subthemes such as “love, caring, and enduring interpersonal ties” (p. 137). Additionally, the researchers found more mixed affect as a result of recalling a meaningful compared to a pleasurable movie, associating, again, meaningful movies with experiences of elevation. Similar themes related to connectedness, meaningfulness, and transcendence have been found when asking participants to describe their impression of one of their favorite movies (Janicke \& Ramasubramanian, 2014). Likewise, Oliver et al. (2012) found that meaningful films, in addition to portraying altruistic values, were also more 
likely than pleasurable films to depict values of human connectedness such as security of the family and one’s loved ones. Moreover, such meaningful films (that included values of connectedness) were associated with heightened feelings of elevation (more so than pleasurable movies), which in turn were positively associated motivations to be a better person and do good things for other people, that is, act prosocially. Together, these findings suggest that media content depicts values related to altruism and human connectedness (cf. Oliver et al. 2012); And such depictions seem to consistently elicit elevation as a form of inspiration that motivates individuals to do better in life and orient towards others (i.e., motivate to act prosocially). Even though the described studies found themes related to love and connectedness portrayals in media, none of them focused on the analyses of these portrayals directly. Oliver and Hartmann’s (2010) and Janicke and Ramasubramanian's (2014) studies only analyzed patterns of participant’s open-ended answers about their media responses. Oliver et al., (2012) only inferred the relevance of connectedness and love portrayals in media by looking at a specific item from the value inventory they used in their study. Consequently, our study focused specifically on measuring portrayals of connectedness, love, and kindness within meaningful compared to pleasurable entertainment and resultant feelings of elevation.

H1: Portrayals of connectedness, love and kindness will be featured more prominently in meaningful films than in pleasurable films.

H2: Elevation will be higher for meaningful films compared to pleasurable films.

\section{Elevation and Connectedness}

Recent research suggests that elevation is not only elicited from experiencing values of altruism, human connectedness and kindness, but elevation also predicts the 
experiences of such values. For example, Diessner et al. (2013) argued that the personality trait of engaging with moral beauty not only elicits the feeling of elevation (cf. Algoe \& Haidt, 2009; Haidt, 2003b; Keltner \& Haidt, 2003), but “appears to be uniquely related to love of, and connectedness to, others” (p. 159). The researchers found that engagement with moral beauty was particularly associated with agreeableness from the Big Five traits (Costa \& McCrae, 1995), benevolence (measured as part of Schwarz’s 10 values system, 1992), love of all humanity, a direct measure of love, and empathy. Furthermore, the researchers showed that an elevating video compared to a non-moral video of admiration, elicited greater levels of gratitude, love, and wanting to be a better person and help others, with trait engagement in moral beauty moderating this outcome. Most relevant for this study, Oliver et al. (2014) found that elevation operated as a mediator for videos portraying care and loyalty in predicting feelings of connectedness with humanity. Also, Oliver et al. (in press) showed that mediated elevation predicts perceptions of shared human goodness, which in turn, through a greater self-humanity overlap, enhances ones feelings of connectedness towards diverse others, and favorable attitudes towards them.

Our study uses a naturalistic approach to measure elevation and connectedness experiences through participant's recollection of a pleasurable or meaningful movie. This approach allows us to explore how a variety of entertainment content the viewer perceives as meaningful, rather than the researcher, can lead to experiences of elevation and connectedness. Based on the findings by Diessner et al., (2013) we also wanted to expand the research on connectedness by further investigating love experiences in relation to elevation. We predicted: 
H3: Elevation will mediate the relationship between meaningful films and experiences of connectedness.

H4: Elevation will mediate the relationship between meaningful films and experiences of compassionate love towards close others and compassionate love towards humanity.

\section{Connectedness and Compassionate Love}

Sprecher and Fehr (2005) understand compassionate love also as altruistic love which is "an attitude towards other(s), either close others or strangers or all of humanity; containing feelings, cognitions, and behaviors that are focused on caring, concern, tenderness, and an orientation toward supporting, helping, and understanding the other(s), particularly when the other(s) is (are) perceived to be suffering or in need” (p. 630). In contrast to empathy, which has been associated with prosocial behavior as well (i.e., Davis, 1996), Sprecher and Fehr (2005) argue that compassionate love is a long-lasting state that may lead to sustained prosocial behavior "including volunteerism directed toward strangers” (p. 631). In support of this argument, these authors found a positive correlation between compassionate love and self-reported helping of others (neighbors, elderly) as well as volunteerism. Volunteerism was specifically predicted by compassionate love for strangers and humanity (instead of towards close others).

Based on this body of research, we predict that feeling touched, moved, inspired, and happy and sad at the same time (i.e., experiencing elevation) from witnessing moral excellence ultimately activates an understanding that we as humans are all interconnected; we are all part of a grand complex of humanity in which every action causes a reaction. It is through this subtle understanding that we are inspired to be kind towards fellow human beings and help when needed. Research has shown that making 
people feel connected to each other by having them read words associated with social connections makes them more likely to act prosocially (i.e., donating to a charity, Pavey, Greitemeyer \& Sparks, 2011). Cialdini, Brown, Lewis, Luce and Neuberg (1997) demonstrated in three experiments that it is the feeling of oneness and thus, connectedness to others, which motivates us to help others. Consistent with Cialdini et al.’s (1997) findings, we predict that we are inspired to help others because we feel we are all sitting in the same boat: Helping and being kind to each other will make fellow boat passengers happy and will make the tumultuous cruise through life alongside everyone much more convenient.

Our argument can also be understood from the theoretical account of Haidt's theory of social space (cf. Haidt, 2000; 2003a; see also Haidt \& Algoe, 2004). Haidt describes elevation as an emotion related to upholding the moral code of divinity (or purity), with disgust representing the comparable opposite emotion from witnessing a violation of the moral value of divinity. Haidt (2003b) argues that people vary on their level of divinity or spiritual purity and pollution on both trait and state levels. For example, he lists food, sexuality, hygiene, and death as elicitors of disgust, and moral beauty, compassion, gratitude, admiration, and generally virtuous behaviors as elicitors of elevation. The latter experience then helps a person to move "up" on the social dimension towards purity and away from pollution. As outlined earlier, Haidt and his colleagues therefore refer to elevation, gratitude, and admiration as self-transcendent emotions, which are those that orient us outwards to serve the greater good. Consequently, to foster these self-transcendent emotions, connectedness towards others is key. Emotions such as elevation then, not only help us to move up on the moral dimension towards the ultimate, 
virtuous, god-like state, but they also serve and satisfy our needs for love and connectedness with others and the transcendent reality (also see Maslow, 1976). In short, we can conceptualize elevation as the accelerator to experience connectedness to others and the transcendent with the result being a heightened feeling of compassionate love towards all humanity. According to Sprecher and Fehr (2005), compassionate love also sparks our motivation for sustained prosocial behavior. Through the feeling of connection to other human beings and possibly a higher transcendent reality, we realize that strangers are not any different from us. Consequently, we not only feel compassion for and feel inclined to help our loved ones, but we also feel compassionate love and prosocial motivations towards strangers and all of humanity. We predicted:

H5: Connectedness will mediate the relationship between elevation and compassionate love towards humanity.

\section{Method}

\section{Participants and procedures}

Two hundred and sixty six students (female 71\%, Mage $=20.43, S D=1.96,76 \%$ White) enrolled in introductory communication classes participated in this research for exchange of a nominal amount of extra credit. Participants were provided with a URL for an online questionnaire and were asked to complete the questionnaire within a time frame of four weeks. After signing the consent form, participants were randomly assigned to name and rate their responses to either a particularly meaningful $(n=139)$ or a particularly pleasurable film $(n=127)$ (see Oliver \& Hartmann, 2010; Oliver et al., 2012).

\section{Measures}


Film genres. After naming their film, participants were asked to indicate the genre(s) that best described their film: Comedy, Action, Adventure, Crime, Romance, History, Animation, Sad Film/Tear Jerker, Drama, Fantasy, Classic, Thriller/Suspense, Biography, Horror, Documentary, and Science Fiction. They were allowed to pick multiple genres. Consistent with prior research (Oliver et al., 2012), those who named a meaningful film were more likely than those that named a pleasurable film to categorize their film into the genres drama, sad film, and history, whereas those naming a pleasurable film were more likely to identify their film as a comedy (see Table 1).

Portrayals of connectedness and kindness. To assess the themes portrayed in the selected films, participants were asked how much $(1=$ not at all, 7 = very much $)$ the film portrayed connectedness, love, and kindness (4 items) or portrayals of pleasure and excitement (3 items). Table 4 lists all items.

Experiences of connectedness. To measure the experience of connectedness, 29 items were adopted based on qualitative responses from participants in Janicke and Ramasubramanian's (2014) study, in which they freely elaborated their impressions of one of their favorite movies. The researchers had categorized these answers to reflect connectedness experiences as well as transcendent experiences. Participants responded on a scale from 1 (not at all) to 7 (very much) how much each item described their experience with the film. An exploratory factor analysis with principal axis factoring was conducted using oblique (promax) rotation. As indicated by the scree plot, three factors were extracted that in combination explained $56 \%$ of variance. Table 2 shows the factor loadings after rotation. Items that cross-loaded on another factor $(\geq .42$, Tabachnick \& Fidel, 2007) were deleted for the subsequent scale construction. An analysis of the items 
revealed that the first factor describes best connectedness towards close others, with specific emphasize on love for each other, including 9 items $(\alpha=.93)$, factor two clearly captures connectedness towards a higher power (12 items, $\alpha=.91$ ), and the third factor (5 items, $\alpha=.91$ ) captures experiences of connectedness towards family, with specific emphasize on gratitude for one’s family.

Elevation and fun. Elevation and fun affect were measured using seven and four items respectively, as previously employed by Oliver et al. (2012). Elevation included the items, touched, moved, emotional, meaningful, compassion, inspired and tender $(M=$ 4.83, $S D=1.71, \alpha=.94)$. Participants indicated how much they experienced each affect while watching the film ( $1=$ not at all, 7 = very much). The same assessment was used to measure the experience of fun affect including the items cheerful, happy, joyful, and upbeat $(M=4.86, S D=1.66, \alpha=.93)$.

Experiences of compassionate love. To measure the experience of compassionate love towards close others and all humanity we adopted seven items for each scale from Sprecher and Fehr's (2005) original personality trait scales. Items were reworded to capture participants' responses related to how the movie made them feel, made them think, and inspired them to act in a compassionate way (Table 3). Responses were again assessed on a 7-point Likert-type scale ranging from 1 (not at all) to 7 (very much). Congruent with Sprecher and Fehr (2005), an exploratory factor analysis confirmed the two factor structure explaining $69 \%$ of variance. As anticipated, all items adopted from the compassionate love towards all humanity and strangers scale loaded on one factor $(M=3.62, S D=1.68, \alpha=.94)$, and all items adopted from the compassionate love towards close others scale loaded on the other factor $(M=4.26, S D=1.64, \alpha=.94)$ 
$\left(r_{\text {factor } 1 \times 2}=.730\right.$, see Table 3$)$. We note that our compassionate love towards all humanity factor contains a strong motivational tendency to show that compassionate love. Thus we conceptualized that factor as compassionate motivation to love humanity.

\section{Results}

\section{Portrayals of Connectedness, Love, and Kindness in Films}

Hypothesis 1 predicted that portrayals of connectedness, love, and kindness would be more frequent in meaningful than pleasurable films. A multivariate analysis of variance (MANOVA) on the seven items related to the portrayals in the two conditions was conducted to examine this hypothesis. Following previous findings by Oliver (1993) on gender differences related to entertainment experiences from dramatic and sad films, we included gender as an additional factor in the analysis. To account for the sample-size differences in gender, we weighted the females group with a weight of .67 and the male group with a weight of 1.92, resulting in $\mathrm{N}=264$ and an equal distribution of gender. This analysis revealed a significant multivariate effect for film condition, $F(7,256)=6.24 p<$ .001 , partial $\eta^{2}=.15$, and gender, $F(7,256)=9.77, p<.001$, partial $\eta^{2}=.21$. The Gender X Film condition interaction was not significant, $F(7,256)=1.62, p=.13$, partial $\eta^{2}=.04$. Table 4 reports the means and univariate statistics for each item between conditions. Gender was significant for the portrayals of lighthearted entertainment, $F(1,263)=5.94$, $p<.05$, partial $\eta^{2}=.02$, love and kindness portrayals, $F(1,263)=49.39, p<.001$, partial $\eta^{2}=.16$, and portrayals of action and suspense, $F(1,263)=19.58, p<.001$, partial $\eta^{2}=$ .069. Films selected by females $(M=4.54, S E=.19)$ included more lighthearted entertainment compared to males $(M=3.92, S E=.19)$, as well as more love and kindness $\left(M_{\text {female }}=5.89, S E=.15 ; M_{\text {male }}=4.35, S E=.15\right)$. In contrast, films selected by males $(M$ 
$=4.77, S E=.18)$ contained more action and suspense compared to females' selected films $(M=3.66, S E=.18)$. In line with our first hypothesis, Table 4 shows that participants in the meaningful condition rated portrayals of connectedness and love and kindness as more central than participants in the pleasurable film condition. On the other hand, participants in the pleasurable film condition indicated that their selected films portrayed life as fun and exciting and simple lighthearted entertainment significantly more so than participants in the meaningful condition. In addition to finding support for our first hypotheses we also regard the result as a successful experimental manipulation of our participants recalling a meaningful or pleasurable film.

\section{Experiences of Elevation, Connectedness and Compassionate Love}

The second hypothesis predicted that elevation would be greater for meaningful compared to pleasurable films. Because we found a main effect for gender for films that portray love and kindness, we again included gender (weighted variable) as an additional factor in the ANOVA analysis, with condition as an independent variable and elevation as the dependent variable. The analysis revealed main effects for condition, $F(1,331)=$ $53.94 p<.001$, partial $\eta^{2}=.14$, and gender, $F(1,331)=33.87, p<.001$, partial $\eta^{2}=.09$. The interaction between gender and condition was not significant, $F(1,331)=.22, p=$ .64 , partial $\eta^{2}=.001$. Participants in the meaningful condition reported greater elevation $(M=5.19, S E=.12)$ than participants in the pleasurable condition $(M=3.93, S E=.13)$, supporting Hypothesis 2 . Females reported greater elevation $\left(M_{\text {weighted }}=5.06, S E=.11\right)$ then males $\left(M_{\text {weighted }}=4.06, S E=.13\right)$. Similarly, for fun emotions, we found main effects for condition, $F(1,331)=7.40, p=.007$, partial $\eta^{2}=.02$, and gender, $F(1,331)=6.65, p$ $=.010$, partial $\eta^{2}=.02$. The interaction between gender and condition was not significant, 
$F(1,331)=.82, p=.365$, partial $\eta^{2}=.002$. Participants in the pleasurable condition reported greater fun affect $(M=5.01, S E=.13)$ than participants in the meaningful condition $(M=4.51, S E=.13)$, and females reported greater fun affect $\left(M_{\text {weighted }}=5.00\right.$, $S E=.12)$ then males $\left(M_{\text {weighted }}=4.52, S E=.14\right)$ independent of condition.

To analyze Hypotheses 3 and 4, multiple mediation analyses using the bootstrapping sampling method (1000 bootstrapped samples, 95\% bias corrected confidence interval) were conducted using the PROCESS macro for SPSS (Preacher \& Hayes, 2004; Preacher, Rucker, \& Hayes, 2007). Across all models, condition predicted elevation significantly after controlling for gender, $F(2,263)=31.19, p<.001 ; R^{2}=.19$. Bootstrapping of the indirect effects of film condition (meaningful film coded $=0$, pleasurable film coded $=1$ ) on connectedness towards close others, controlling for gender $(\beta=.657, \mathrm{t}=4.926, p<.001)$, revealed a significant indirect effect of elevation $(\beta=-$ $.773,95 \%$ CI: [-1.051, -.5311], $\left.F(3,262)=152.52, p<.001 ; R^{2}=.64\right)$. Females reported greater feelings of connectedness towards close others after recalling one of their favorite films $(M=5.421, S D=1.36)$ compared to males $(M=4.15, S D=1.51)$. The same mediation was found for elevation on the relationship between film condition and connectedness towards a higher power ( $\beta=-.48,95 \%$ CI: [-.703, -.299]) and for connectedness towards family ( $\beta=-.68,95 \%$ CI: $[-.943,-.444])$. Gender was not a significant covariate for the latter two models. Thus, participants in the meaningful condition experienced greater elevation, which, in turn, was associated with higher reports of connectedness towards close others, a higher power, and towards family, supporting H3. 
Next, we examined the mediation effect for elevation on film condition and the two compassionate love experiences, again controlling for gender. Again, elevation fully mediated the relationship between film condition and compassionate love towards close others $(\beta=-.79,95 \% \mathrm{CI}:[-1.077,-.561])$ and compassionate motivation to love humanity ( $\beta=-.71,95 \% \mathrm{CI}$ [ [-.957, -.478]), supporting H4. Gender was not a significant covariate in either of the models. Figure 1 summarizes the results for all dependent variables graphically. The results support our hypotheses that elevation is a significant mediator for experiences of connectedness and compassionate love from meaningful compared to pleasurable films.

---Figure 1 here---

\section{Connectedness as a Mediator between Elevation and Compassionate Love}

Hypothesis 5 predicted that connectedness will mediate the relationship between elevation and compassionate love towards humanity. To investigate this hypothesis, an additional mediation analysis was conducted, treating measures of connectedness towards a higher power, towards close others, and towards family as mediators, and motivation to love humanity as a dependent variable. After controlling for gender and condition, the analysis revealed a full mediation effect for connectedness towards a higher power $(\beta=$ $.119,95 \%$ CI: [.067, - .187]), and connectedness towards family ( $\beta=.176,95 \% \mathrm{CI}$ : [.095, - .278]), but not for connectedness towards close others $(\beta=.038,95 \%$ CI: [-.095, - .165], $\left.F(6,259)=41.13, p<.001 ; R^{2}=.49\right)$.

Independent of condition and gender, connectedness towards a higher power and family are the processes through which elevation predicts ones motivation to love humanity, supporting H5. Figure 2 depicts the model graphically. 
---Figure 2 here---

\section{Discussion}

The purpose of this study was to expand the research on the effects of meaningful entertainment investigating responses to films, that previous research indicated to be related to elevation: Connectedness and compassionate love. First, we tested the assumption that portrayals of connectedness, love and kindness are relevant more so in meaningful compared to merely pleasurable entertainment (H1). In relation to previous studies we also expected to see greater elevation from meaningful entertainment compared to pleasurable fare (H2). Furthermore, we expanded on previous findings that linked meaningful entertainment to experiences of connectedness to humanity, as mediated by elevation, by employing previously explored audience responses of connectedness. This allowed us to further connect entertainment content with specific state experiences of connectedness rather than trait measures related to people’s individual propensity to experience connectedness towards humanity as measured before (using Piedmont’s (1999) and Phillip and Ziller’s (1997) scales). Further, we investigated connectedness and compassionate love as outcomes of meaningful entertainment that elicits elevation, based on previous associations between moral beauty and the experiences of love (i.e., Diessner et al., 2013) (H3, 4). In addition, we wanted to explore the effects of connectedness experiences as a mediator for the relationship between elevation and compassionate love experiences, specifically as related to ones compassionate feelings and prosocial tendencies towards all of humanity (H5). That is, we argued that feeling elevation ultimately makes us realize the interconnectedness between humanity and brings out the compassionate love we feel towards humanity 
including a motivation to help even strangers. Based on Haidt’s (2000, 2003b)

understanding of divinity as the third dimension of social space, we argued that meaningful entertainment can move us up on the divinity dimension of social space, transforming us to more pure, moral beings. The self-transcendent emotion of elevation, we argued, brings about this transformation through the understanding of the interconnectedness of all humanity and the transcendent.

As expected, popular entertainment portrayals that were seen as meaningful compared to pleasurable included significantly more portrayals of the interconnectedness of the world, how any action causes a reaction, family interconnectedness, and love and kindness. Such meaningful portrayals then also elevate viewers more so than purely pleasurable portrayals that depict life as fun and exciting or that are simple lighthearted depictions. Females experienced more of such meaningful feelings of tenderness, inspiration, and compassion across conditions, supporting previous findings (i.e., Landis et al., 2009; Oliver et al., 2012).

Additionally, supporting our hypotheses, we found elevation to be a mediator for the experiences of connectedness and compassionate love as depicted from meaningful compared to pleasurable films. Expanding upon the findings by Oliver et al. (2014), our study showed that meaningful films that portray connectedness and love and kindness not only elevated people, but also made them realize the importance of human bonds and love in life (connectedness toward close others) and gratitude toward one's family (connectedness towards family). The films further gave them a glimpse of a transcendent aspect of reality (connectedness towards a higher power). Thus, meaningful films not only elicited greater elevation than films focused on simple lighthearted entertainment, 
but this inspirational, moving, and tender feeling also lead to revelations of the transcendent aspects of reality, a higher power connecting life and understanding that things are part of a larger whole (among others). Our results also support findings by Landis et al. (2009) who demonstrated a moderately strong correlation between spiritual transcendence (as measured by Piedmont, 1991) and elevation $(r=.45)$. Future studies could further explore how this connectedness experience with a higher power translates into raising personal morality and/or spirituality. More specifically it would be interesting to see whether meaningful media that portrays certain moral domains (i.e., Oliver et al., 2014) can, over time, increase the salience of a specific moral domain through the process of elevation and experiences of connectedness to humanity and the transcendent.

Lastly, a unique contribution of the study to the scholarship of positive media psychology is the exploration of the third dimension of social space as introduced by Haidt (2000, 2003b). That is, we found that transcendent experiences (connectedness to a higher power) that, inspired by elevation, can make us move up on the dimension of divinity, also seem to motivate us to feel and act compassionately towards strangers and humanity (H5). Firstly, this finding points out that mainstream entertainment, which is perceived as meaningful by the consumer, can affect aspects of self-realization (Vorderer, 2001) that go beyond the pleasing of self interested, fleeting emotions or thoughts.

Whereas emotions such as elevation makes us more outward oriented and more connected and grateful for our families; connected towards close others and appreciative of love we experience towards those; and more connected towards the transcendent; these experiences may ultimately serve our self interests to grow as a moral person and thus, rise on the divinity dimension of social space (Haidt, 2000). 
Secondly, and as shown by Cialdini et al. (1997), the experience of feeling connected, and specifically connected to a higher power, ultimately can increase our concern about the well-being of others, motivating us to help people we don't know personally (compassionate motivation to love humanity). In short, experiencing the higher power through elevation, can make us think more about the well-being of humankind, wanting to be more kind and good to fellow human beings, and wanting to reach out to people we don't know that are having a hard time (motivation to love humanity items, see Table 3).

Similarly, connectedness towards family has also been shown to mediate the relationship between mediated elevation and ones motivation to love all of humankind. As mentioned before, connectedness towards family specifically includes experiences of gratitude for ones family. As Haidt and his colleagues (i.e., Haidt \& Morris, 2009) pointed out, gratitude counts as one of the self-transcendent emotions that open oneself up to others. Similarly, Frederickson (2004) argues that gratitude is another positive emotion that broadens and builds. Others have found a relationship between gratitude and prosocial behavior (i.e., Emmons \& McCullough, 2003) as well as compassion and prosocial behavior (i.e., Leiberg, Klimecki \& Singer, 2011). Thus, our findings support previous literature that demonstrates a link between gratitude (towards one's family in this case) and one's motivation to be good and do good for others in need (i.e., motivation to love humanity). More specifically, our findings show that this motivation to love humanity can indirectly be elicited through elevating entertainment experiences.

We think these findings have important theoretical and practical implications for the positive power entertainment media can have on transforming viewers and ultimately 
society. In fact, media content that is inspiring, elevating, or fostering kindness, compassion, and gratitude is strongly on the rise (see, for example, ServiceSpace.com). Not only have newspapers developed sections for good news (i.e. Huffington Post good news) but also online videos depicting extreme acts of kindness frequently go viral (i.e., free hug campaign). Inspiring and uplifting images from all over the world are shared on social media (i.e., Humans of New York), and even inspiring advertisements (i.e., P\&G’s Thank you Mom) are now commonplace in the current media landscape. With an increase in exposure to such fare, it is only a matter of time before consumers can utilize the benefits of this inspiring content for their own moral development.

\section{Limitations and Future Research}

While the study introduces some new concepts to the field of meaningful entertainment, we recognize several limitations. First, we relied on participants remembering a particular meaningful or pleasurable film, in contrast to exposing them to certain pretested videos. The advantage of the latter is the creation of a strong treatment for the elicitation of the experiences of interest (i.e. elevation, connectedness, compassion); however it reduces external validity. On the other hand, recalling a film experience increases external validity but decreases internal validity and reduces the treatment strength, thus, limiting the conclusions that can be drawn from the self-reported experiences. However, without a content analytic basis on the values and themes portrayed in meaningful films to draw from, the selection of our method seems most reasonable. In fact, we were able to show that across over 90 different selected movies, (in the meaningful condition) connectedness, love, and kindness were more likely to be seen than in pleasurable movies. In addition, even with this great variety of films we were 
able to find our predicted relationships, justifying our method of choice. Nevertheless, future experimental research needs to further explore more systematically the different values and portrayals in media content, which lead to elevation and other transcendent emotions (i.e., Oliver et al., 2014).

Furthermore, even though this study is amongst the first to investigate experiences compassionate love as derived from popular entertainment films, the link between prosocial intentions and actual prosocial behavior is still unexplored. Given the strength of the relationships between elevating entertainment media and connectedness and motivation to love humanity, future research could investigate people’s actual helping behaviors through an experimental approach (i.e., Condon, Desbordes, Miller \& DeSteno, 2013).

Lastly, when it comes to measuring meaningful media experiences, gender and age of the participants cannot be disregarded. Hofer, Alemand and Martin (2014) have shown that eudaimonic media experiences become specifically relevant later in life. Thus, it is reasonable to expect that older participants are not only more prone to seek out eudaimonic media content more frequently (cf. Oliver \& Raney, 2011), but, based on their greater life experiences, are also more likely to retrieve stronger feelings of connectedness and compassionate love from such entertainment. To generalize the results of the current study, a random sample from the general population with a larger age range is warranted.

\section{Conclusion}

Our research is among the first that directly identified connectedness, love, and kindness to be values that are more prevalent in meaningful compared to pleasurable 
entertainment as identified by a sample of college students. Additionally, we found that elevation is a mediator for meaningful films and experiences of connectedness towards a higher power (the transcendence), connectedness towards close others (specifically as related to love), connectedness towards family (specifically as related to gratitude), compassionate love towards close others, and compassionate motivation to love humanity and help strangers. Specifically, connectedness towards the higher power and appreciation for ones family and loved ones mediated the relationship between mediated elevation and ones motivation to be there for others in need. This not only expands our understanding of meaningful entertainment experiences, but has further implications for the development of personal morals, kind behaviors (kindness as a response to compassion), and gratitude from entertainment fare. We hope to have broadened the research avenues to further explore these transcendent emotions as a result of media experiences and their potential to impact individuals and society for the better. 


\section{References}

Algoe, S.B., \& Haidt, J. (2009). Witnessing excellence in action: The'other-praising’ emotions of elevation, gratitude, and admiration. Journal of Positive Psychology, 4, 105-27. doi: 10.1080/17439760802650519

Aquino, K. , McFerran, B., \& Laven, M. (2011). Moral identity and the experience of moral elevation in response to acts of uncommon goodness. Journal of Personality and Social Psychology, 100, 703-718. doi: 10.1037/a0022540.

Baumeister, R. F., Vohs, K.D., Aaker, J. L., Garbinsky, E.N. (2013). Some key differences between a happy life and a meaningful life. The Journal of Positive Psychology, 505-516. doi: 10.1080/17439760.2013.830764

Bartsch, A. (2012). Emotional gratification in entertainment experience. Why viewers of movies and television series find it rewarding to experience emotions. Media Psychology, 15(3), 267-302. Doi: 10.1080/15213269.2012.693811

Bosshart, L., \& Macconi, I. (1998). Defining “entertainment.” Communication Research Trends, 18(3), 3-6.

Condon, P., Desbordes, G., Miller, W. B., \& DeSteno, D. (2013). Meditation increases compassionate responses to suffering. Psychological Science, 24(10), 2125-2127. doi:10.1177/0956797613485603

Cialdini, R. B., Brown, S. L., Lewis, B.P., Luce, C., Neuberg, S. L. (1997). Reinterpreting the empathy-altruism relationship: When one into one equals oneness. Journal of Personality and Social Psychology, 73(3), 481-

494. http://dx.doi.org/10.1037/0022-3514.73.3.481 
Costa, P. T., \& McCrae, R. R. (1995). Domains and facets: Hierarchical personality assessment using the revised neo personality inventory. Journal of Personality Assessment, 64, 21-50.

Davis, M. H. (1996). Empathy: A social psychological approach. Boulder, CO: Westview Press.

Diessner, R., Iyer, R., Smith, M., M., Haidt, J. (2013). Who engages with moral beauty? Journal of Moral Education, 42, 139-163. DOI: 10.1080/03057240.2013.785941

Diessner, R., Solom, R. D., Frost, N. K., Parsons, L., \& Davidson, J. (2008). Engagement with beauty: Appreciating natural, artistic, and moral beauty. The Journal of Psychology, 142(3), 303-332. doi: 10.3200/JRLP.142.3.303-332.

Eden, A., Hartmann, T., Oliver, M. B., \& Mares, M. L. (2013, June). Elevation! Only if you care: Examining the determinants of users' elevation responses to short film clips. Paper presented at the annual meeting of the International Communication Association, London, UK.

Emmons, R. A. \& McCullough, M. E. (2003). Counting blessings versus burdens: An experimental investigation of gratitude and subjective well-being in daily life. Journal of Personality and Social Psychology, 84(2), 377-389.

Fredrickson, B. L. (2004). Gratitude, like other positive emotions, broadens and builds. In R. A. Emmons \& M. E. McCullough (Eds.), The Psychology of Gratitude (pp. 145-166). New York, NY: Oxford University Press.

Garland, E., L., Frederickson, B., L., Kring, A., M., Johnson, D., P., Meyer, P., S., \& Penn, D., L., (2010). Upward spirals of positive emotions counter downward spirals of negativity: insights from the broaden-and-build theory and affective 
neuroscience on the treatment of emotion dysfunctions and deficits in psychopathology. Clinical Psychology Review, 30(7), 849-864. doi:

10.1016/j.cpr.2010.03.002

Haidt, J. (2003a). The moral emotions. In R.J. Davidson, K.R. Scherer, \& H.H.

Goldsmith (Eds.), Handbook of affective sciences (pp. 852-870). Oxford, England: Oxford University Press.

Haidt, J. (2003b). Elevation and the positive psychology of morality. In C.L.M. Keyes \& J. Haidt (Eds.), Flourishing: Positive psychology and the life well-lived (pp. 275289). Washington, DC:American Psychological Association.

Haidt, J. (2000). The positive emotion of elevation. Prevention \& Treatment, 3, Article 3. Retrieved from http://psycnet.apa.org/journals/pre/3/1/3c.html

Haidt, J., \& Algoe, S. (2004). Moral amplification and the emotions that attach us to saints and demons. In J. Greenberg, S. L. Koole, \& Tom Pyszczynski (Eds.) Handbook of experimental existential psychology. New York: Guilford. pp. 322335.

Haidt, J., \& Joseph, C. (2004). Intuitive Ethics: How Innately Prepared Intuitions Generate Culturally Variable Virtues. Daedalus, 55-66.

doi:10.1162/0011526042365555

Haidt, J., \& Morris, J. P. (2009). Finding the self in self-transcendent emotions. Proceedings of the National Academy of Sciences, 106, 7687-7688. $\square$ doi: 10.1073/pnas.0903076106 
Haidt, J. \& Keltner, D. (2004). Appreciation of beauty and excellence. In C. Peterson and M. E. P. Seligman (Eds.) Character strengths and virtues. Washington DC: American Psychological Association Press. pp. 537-551.

Hofer, M. (2013). Appreciation and enjoyment of meaningful entertainment: The role of mortality salience and search for meaning in life. Journal of Media Psychology: Theories, Methods, and Applications, 25(3), 109-117. doi: 10.1027/18641105/a000089

Hofer, M., Alemand, M., \& Martin, M. (2014). Age differences in nonhedonic entertainment experiences. Journal of Communication, 64(1), 61-81. doi:10.1111/jcom.12074

Janicke, S. H., \& Ramasubramanian, S. (November, 2014). Positive emotions, spiritual beliefs, trait transcendence, and media enjoyment. To be presented at the Annual National Communication Association, November, 2014, Chicago, IL (under review at the Journal of Media Psychology)

Kashdan, T., B., Biswas-Diener, R., King, L., A. (2008). Reconsidering happiness: The costs of distinguishing between hedonics and eudaimonia. The Journal of Positive Psychology, 3, 219-233. DOI: 10.1080/17439760802303044

Keltner, D., \& Haidt, J. (2003). Approaching awe: A moral, spiritual, and aesthetic emotion. Cognition \& Emotion, 17, 297-314. DOI: 10.1080/02699930302297

Klimmt C. (2011). Media psychology and complex modes of entertainment experiences. Journal of Media Psychology: Theories, Methods, and Applications, 23(1), 34-38. doi: 10.1027/1864-1105/a000030 
Knobloch-Westerwick, S., Gong, Y., Hagner, H., Kerbeykian, L. (2013). Tragedy viewers count their blessings. Feeling low on fiction leads to feeling high on life. Communication Research, 40(6), 747-766. Doi: 10.1177/0093650212437758

Landis, S. K., Sherman, M. F., Piedmont, R. L., Kirkhard, M. W., Rapp, E. M., Bike, D. H. (2009). The relation between elevation and self-reported prosocial behavior: Incremental validity over the Five-Factor Model of Personality. The Journal of Positive Psychology, 4(1), 71-84. Doi: 10.1080/17439760802399208

Leiberg S, Klimecki O, Singer T (2011) Short-term compassion training increases prosocial behavior in a newly developed prosocial game. PLoS ONE, 6(3): e17798. doi:10.1371/journal.pone.0017798

Lewis, R. J., Tamborini, R., \& Weber, R. (2014). Testing a dual-process model of media enjoyment and appreciation. Journal of Communication, 64(3), 397-416. doi:10.1111/jcom.12101

Maslow, A. H. (1976). Religions, values, and peak experiences. New York: Penguin.

Oliver, M. B. (1993). Exploring the paradox of the enjoyment of sad films. Human Communication Research, 19, 314-342. DOI: 10.1111/j.14682958.1993.tb00304.x

Oliver, M. B., Ash, E., Kim, K., Woolley, J. K., Hoewe, J., Shade, D. D., Chung, M. (in press). Media induced elevation as a means of enhancing feelings of intergroup connectedness. Journal of Social Issues.

Oliver, M. B., \& Bartsch, A. (2010). Appreciation as audience response: exploring entertainment gratifications beyond hedonism. Human Communication Research, 36(1), 53-81. doi:10.1111/j.1468-2958.2009.01368.x 
Oliver, M.B. \& Bartsch, A. (2011). Appreciation of entertainment. The importance of meaningfulness via virtue and wisdom. Journal of Media Psychology: Theories, Methods, and Applications, 23(1), 29-33. doi:10.1027/1864-1105/a000029

Oliver, M.B., \& Hartmann, T. (2010). Exploring the role of meaningful experiences in users’ appreciation of “good movies”. Projections, 4(2), 128-150.doi: 10.3167/proj.2010.040208

Oliver, M. B., Hartmann, T., \& Woolley, J.K. (2012). Elevation in response to entertainment portrayals of moral virtue. Human Communication Research, 38(3), 360-378. doi: 10.1111/j.1468-2958.2012.01427.x

Oliver, M. B., Hoewe, J., Kim, K., Shade, D., \& Bailey, E. (2014, May). The Influence of media portrayals of care, loyalty, and purity on elevation and connectedness with humanity. Paper presented at the International Communication Association, Seattle, WA.

Oliver, M.B., \& Raney, A. A. (2011). Entertainment as pleasurable and meaningful: Identifying hedonic and eudaimonic motivations for entertainment consumption. Journal of Communication, 61(5), 984-1004. doi:10.1111/j.14602466.2011.01585.x

Pavey, L., Greitemeyer, T., Sparks, P. (2011). Highlighting relatedness promotes prosocial motives and behavior. Personality and Social Psychology Bulletin, 37(7), 905-917. doi:10.1177/0146167211405994

Piedmont, R. L. (1999). Does spirituality represent the sixth factor of personality? Spiritual transcendence and the five-factor model. Journal of Personality, 67(6), 985-1013. doi: 10.1111/1467-6494.00080 
Phillips, S. T., \& Ziller, R. C. (1997). Toward a theory and measure of the nature of nonprejudice. Journal of Personality and Social Psychology, 72(2), 420-434. doi: $10.1037 / / 0022-3514.72 .2 .420$

Preacher, K. J., \& Hayes, A. F. (2004). SPSS and SAS procedures for estimating indirect effects in simple Mediation models. Behavior Research Methods, Instruments, \& Computers, 36, 717-731. Doi: 10.3758/BF03206553

Preacher, K. J., Rucker, D. D., \& Hayes, A. F. (2007). Addressing moderated Mediation hypotheses: Theory, methods, and prescriptions. Multivariate Behavioral Research, 42, 185-227. Doi: 10.1080/00273170701341316

Schindler, I., Zink, V., Windrich, J., \& Menninghaus, W. (2013). Admiration and adoration: their different ways of showing and shaping who we are. Cognition and Emotion, 27(1), 85-118. doi: 10.1080/02699931.2012.698253

Schwartz, S. H. (1992). Universals in the content and structure of values: Theoretical advances and empirical tests in 20 countries. Advances in Experimental Social Psychology, 25, 1-65. doi: 10.1016/S0065-2601(08)60281-6

Sprecher, S., \& Fehr, B. (2005). Compassionate love for close others and humanity. Journal of Social and Personal Relationships, 22, 629-651. Doi:

\subsection{7/0265407505056439}

Tabachnick, B. G., \& Fidell, L. S. (2007). Using multivariate statistics (5th ed.). Upper Saddle River, NJ: Pearson Allyn \& Bacon.

Vorderer, P. (2001). It's all entertainment, sure. But what exactly is entertainment? Communication research, media psychology, and the explanation of entertainment experiences. Poetics, 29, 247-261 
Vorderer, P., Klimmt, C. \& Ritterfeld, U. (2004). Enjoyment: At the heart of media entertainment. Communication Theory, 14(4), 388-408. Doi: 10.1016/S0304$422 X(01) 00037-7$

Wirth, W., Hofer, M., \& Schramm, H. (2012). Beyond pleasure: Exploring the eudaimonic entertainment experience. Human Communication Research, 38, 406428. doi:10.1111/j.1468-2958.2012.01434.x 
Table 1

Percent of Participants Identifying Their Self-Selected Film to Specific Genres

\begin{tabular}{|c|c|c|c|c|}
\hline \multirow[b]{2}{*}{ Genre } & \multicolumn{2}{|c|}{ Film Condition } & \multirow[b]{2}{*}{$\mathrm{Chi}^{2}(d f=1)$} & \multirow[b]{2}{*}{ Cramer's V } \\
\hline & Meaningful & Pleasurable & & \\
\hline Comedy & $39 \%$ & $59 \%$ & $10.892 * *$ & 0.202 \\
\hline Drama & $54 \%$ & $38 \%$ & 7.583* & 0.169 \\
\hline Sad film/tear jerker & $24 \%$ & $13 \%$ & $5.756 *$ & 0.147 \\
\hline History & $15 \%$ & $6 \%$ & $5.497 *$ & 0.144 \\
\hline Animation & $4 \%$ & $8 \%$ & 1.41 & 0.073 \\
\hline Romance & $44 \%$ & $37 \%$ & 1.262 & 0.069 \\
\hline Biography & $7 \%$ & $4 \%$ & 0.911 & 0.059 \\
\hline Documentary & $4 \%$ & $2 \%$ & 0.816 & 0.055 \\
\hline Thriller/Suspense & $10 \%$ & $13 \%$ & 0.634 & 0.049 \\
\hline Crime & $5 \%$ & $6 \%$ & 0.173 & 0.026 \\
\hline Horror & $3 \%$ & $2 \%$ & 0.08 & 0.017 \\
\hline Fantasy & $11 \%$ & $10 \%$ & 0.036 & 0.012 \\
\hline Science fiction & $5 \%$ & $6 \%$ & 0.021 & 0.009 \\
\hline Action Adventure & $22 \%$ & $22 \%$ & 0.001 & 0.002 \\
\hline
\end{tabular}

${ }^{*} p<.05 .{ }^{* *}, p<.001$. 
Table 2

Results of the EFA with Promax Rotation for Connectedness Experiences

\begin{tabular}{|c|c|c|c|}
\hline & Factor 1 & Factor 2 & Factor 3 \\
\hline The movie... & $\begin{array}{l}\text { Connectedness } \\
\text { towards close } \\
\text { others }\end{array}$ & $\begin{array}{l}\text { Connectedness } \\
\text { towards a } \\
\text { higher power }\end{array}$ & $\begin{array}{l}\text { Connectedness } \\
\text { towards family }\end{array}$ \\
\hline $\begin{array}{l}\text { made me think about the power of } \\
\text { love }\end{array}$ & .929 & -.031 & -.172 \\
\hline $\begin{array}{l}\text { Made me realize that love and being } \\
\text { loves is a great gift in life }\end{array}$ & .877 & -.016 & -.017 \\
\hline $\begin{array}{l}\text { made me realize the importance of } \\
\text { relationships }\end{array}$ & .851 & -.119 & -.007 \\
\hline $\begin{array}{l}\text { made me feel how important human } \\
\text { bonds are }\end{array}$ & .797 & .092 & -.051 \\
\hline $\begin{array}{l}\text { Taught me that love and kindness to } \\
\text { others are the key to a fulfilling life }\end{array}$ & .779 & -.029 & .088 \\
\hline $\begin{array}{l}\text { Made me feel happy to have the } \\
\text { people in my life that make me feel } \\
\text { loved }\end{array}$ & .756 & -.041 & .186 \\
\hline $\begin{array}{l}\text { Made me feel like faith and love } \\
\text { can accomplish miracles }\end{array}$ & .697 & .028 & .026 \\
\hline $\begin{array}{l}\text { Made me cherish the people in my } \\
\text { life }\end{array}$ & .595 & .058 & .302 \\
\hline Showed me the value of friendship & .421 & -.082 & .284 \\
\hline $\begin{array}{l}\text { Made me feel like I can merge with } \\
\text { a power or force greater than myself }\end{array}$ & -.117 & .838 & .016 \\
\hline $\begin{array}{l}\text { Revealed a transcendent aspect to } \\
\text { reality }\end{array}$ & -.207 & .775 & .032 \\
\hline $\begin{array}{l}\text { Made all things appear to be part of } \\
\text { a larger whole }\end{array}$ & .136 & .770 & -.159 \\
\hline $\begin{array}{l}\text { Feel like I could transcend space } \\
\text { and time }\end{array}$ & -.304 & .720 & .196 \\
\hline Gave me a spiritual experience & .025 & .721 & -.048 \\
\hline $\begin{array}{l}\text { Made me feel like I could go } \\
\text { beyond my normal everyday sense } \\
\text { of self }\end{array}$ & -.047 & .709 & .055 \\
\hline Made me feel mystical & -.251 & .678 & .092 \\
\hline
\end{tabular}




\begin{tabular}{|c|c|c|c|}
\hline & Factor 1 & Factor 2 & Factor 3 \\
\hline The movie... & $\begin{array}{l}\text { Connectedness } \\
\text { towards close } \\
\text { others }\end{array}$ & $\begin{array}{l}\text { Connectedness } \\
\text { towards a } \\
\text { higher power }\end{array}$ & $\begin{array}{l}\text { Connectedness } \\
\text { towards family }\end{array}$ \\
\hline $\begin{array}{l}\text { Made me feel like all things are } \\
\text { divine }\end{array}$ & .094 & .677 & .017 \\
\hline $\begin{array}{l}\text { Made me feel like there is a higher } \\
\text { power connecting everything in life }\end{array}$ & .195 & .647 & -.089 \\
\hline $\begin{array}{l}\text { Gave me a feeling that I cannot put } \\
\text { in words }\end{array}$ & .106 & .631 & -.075 \\
\hline $\begin{array}{l}\text { Made me feel like there is a life } \\
\text { outside of everyone's present } \\
\text { situation }\end{array}$ & .251 & .546 & -.103 \\
\hline Revealed the nature of reality & .118 & .513 & -.029 \\
\hline Made me want to be with my family & .142 & .055 & .698 \\
\hline $\begin{array}{l}\text { Made me appreciate my family and } \\
\text { how every minute we spend } \\
\text { together should be full of laughter } \\
\text { and less fighting }\end{array}$ & .213 & .021 & 672 \\
\hline $\begin{array}{l}\text { Made me be thankful for my family } \\
\text { and every moment I have with them }\end{array}$ & .268 & .050 & 638 \\
\hline $\begin{array}{l}\text { Reminds me of the importance of } \\
\text { family }\end{array}$ & .313 & .004 & .599 \\
\hline $\begin{array}{l}\text { Gave me a sense of gratitude for the } \\
\text { wealth I have of friends and family }\end{array}$ & .308 & -.031 & .538 \\
\hline Factor 1 (Pearson’s r) & & $.379 * *$ & $.614^{* *}$ \\
\hline Factor 2 & & & $.313^{* *}$ \\
\hline Eigenvalue (after rotation) & 10.83 & 4.32 & 1.04 \\
\hline
\end{tabular}

$* * p<.001$ 
Table 3

Results of the EFA with Promax Rotation for Compassionate Love Experiences

\begin{tabular}{|c|c|c|}
\hline & Factor 1 & Factor 2 \\
\hline The movie & $\begin{array}{l}\text { Compassionate } \\
\text { motivation to love } \\
\text { humanity/strangers }\end{array}$ & $\begin{array}{l}\text { Compassionate } \\
\text { love towards close } \\
\text { others }\end{array}$ \\
\hline $\begin{array}{l}\text { Made me want to help others that I don't } \\
\text { even know }\end{array}$ & .979 & -.103 \\
\hline $\begin{array}{l}\text { Made me feel compassionate love for people } \\
\text { from everywhere }\end{array}$ & .778 & .081 \\
\hline $\begin{array}{l}\text { Made me think about the well-being of } \\
\text { humankind }\end{array}$ & .774 & .004 \\
\hline $\begin{array}{l}\text { Made me want to understand rather than } \\
\text { judge people who are strangers to me }\end{array}$ & .771 & .055 \\
\hline $\begin{array}{l}\text { Made me want to sacrifice in order to let } \\
\text { people from other places who are less } \\
\text { fortunate achieve their goals }\end{array}$ & .767 & .060 \\
\hline $\begin{array}{l}\text { Made me want to reach out to people I don't } \\
\text { know that are having a hard time }\end{array}$ & .750 & 118 \\
\hline $\begin{array}{l}\text { Made me want to be kind and good to fellow } \\
\text { human beings }\end{array}$ & .696 & .165 \\
\hline $\begin{array}{l}\text { Made me feel compassionate for my friends } \\
\text { and family members when they go through a } \\
\text { difficult time }\end{array}$ & -.054 & .932 \\
\hline $\begin{array}{l}\text { Made me feel compassionate love for those } \\
\text { people important in my life }\end{array}$ & -.011 & .883 \\
\hline $\begin{array}{l}\text { Made me feel concerned about the well- } \\
\text { being of those people close to me }\end{array}$ & .030 & .770 \\
\hline $\begin{array}{l}\text { Made me want to help a person that is close } \\
\text { to me no matter at which cost }\end{array}$ & .137 & .753 \\
\hline $\begin{array}{l}\text { Made me want to be good and kind to my } \\
\text { friends and family members }\end{array}$ & .072 & .748 \\
\hline $\begin{array}{l}\text { Made me feel like I would rather suffer } \\
\text { myself than see someone close to me suffer }\end{array}$ & .031 & .733 \\
\hline $\begin{array}{l}\text { Made me open to accept friends and family } \\
\text { members even when they do things I think } \\
\text { are wrong }\end{array}$ & 145 & .678 \\
\hline Eigenvalues & 8.54 & 1.06 \\
\hline
\end{tabular}


Table 4

Relevance of Values as Portrayed in Meaningful Versus Pleasurable Films

\begin{tabular}{|c|c|c|c|c|c|c|}
\hline \multirow[b]{3}{*}{ Values (The film portrayed...) } & \multicolumn{4}{|c|}{ Film Condition } & & \\
\hline & \multicolumn{2}{|c|}{ Meaningful } & \multicolumn{2}{|c|}{ Pleasurable } & \multicolumn{2}{|c|}{ Univariate $F$} \\
\hline & $M$ & $S E$ & $M$ & $S E$ & $F(1,263)$ & $\eta^{2}$ \\
\hline \multicolumn{7}{|l|}{ Connectedness } \\
\hline how everything in the world is & 4.464 & .16 & 3.85 & .163 & 7.313* & .027 \\
\hline \multicolumn{7}{|l|}{ interconnected } \\
\hline how any action causes a reaction & 5.886 & .116 & 5.511 & .122 & $4.962 *$ & .019 \\
\hline the importance of family & 5.143 & .170 & 4.36 & .179 & $9.833^{*}$ & .036 \\
\hline \multicolumn{7}{|l|}{ interconnectedness for ones } \\
\hline \multicolumn{7}{|l|}{ happiness } \\
\hline the importance of love and & 5.535 & .150 & 4.704 & .158 & $14.587 * *$ & .053 \\
\hline \multicolumn{7}{|l|}{ kindness with each other } \\
\hline \multicolumn{7}{|l|}{ Fun/Pleasure } \\
\hline how life is fun and exciting & 4.385 & .154 & 5.124 & .162 & $10.886 *$ & .040 \\
\hline simple lighthearted & 3.806 & .184 & 4.654 & .193 & $10.141^{*}$ & .032 \\
\hline \multicolumn{7}{|l|}{ entertainment } \\
\hline action and suspense & 4.282 & .172 & 4.144 & .181 & .305 & .001 \\
\hline
\end{tabular}




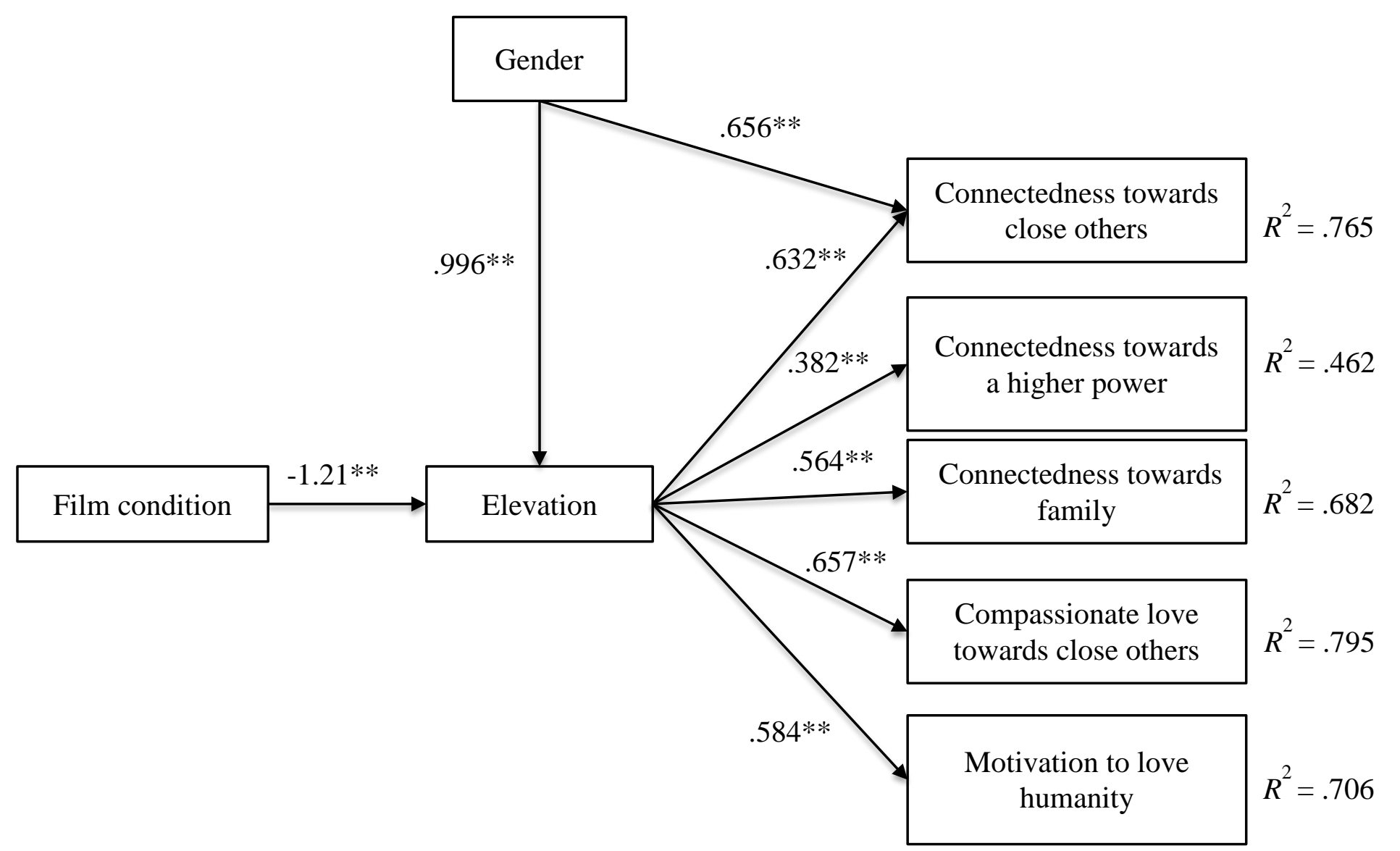

Note: None of the direct effects of film condition to the dependent variables was significant.

Unstandardized coefficients are reported. $R^{2}$ for the indirect effects are reported.

Figure 1. Results of the mediation analyses for Hypotheses 3 and 4. 


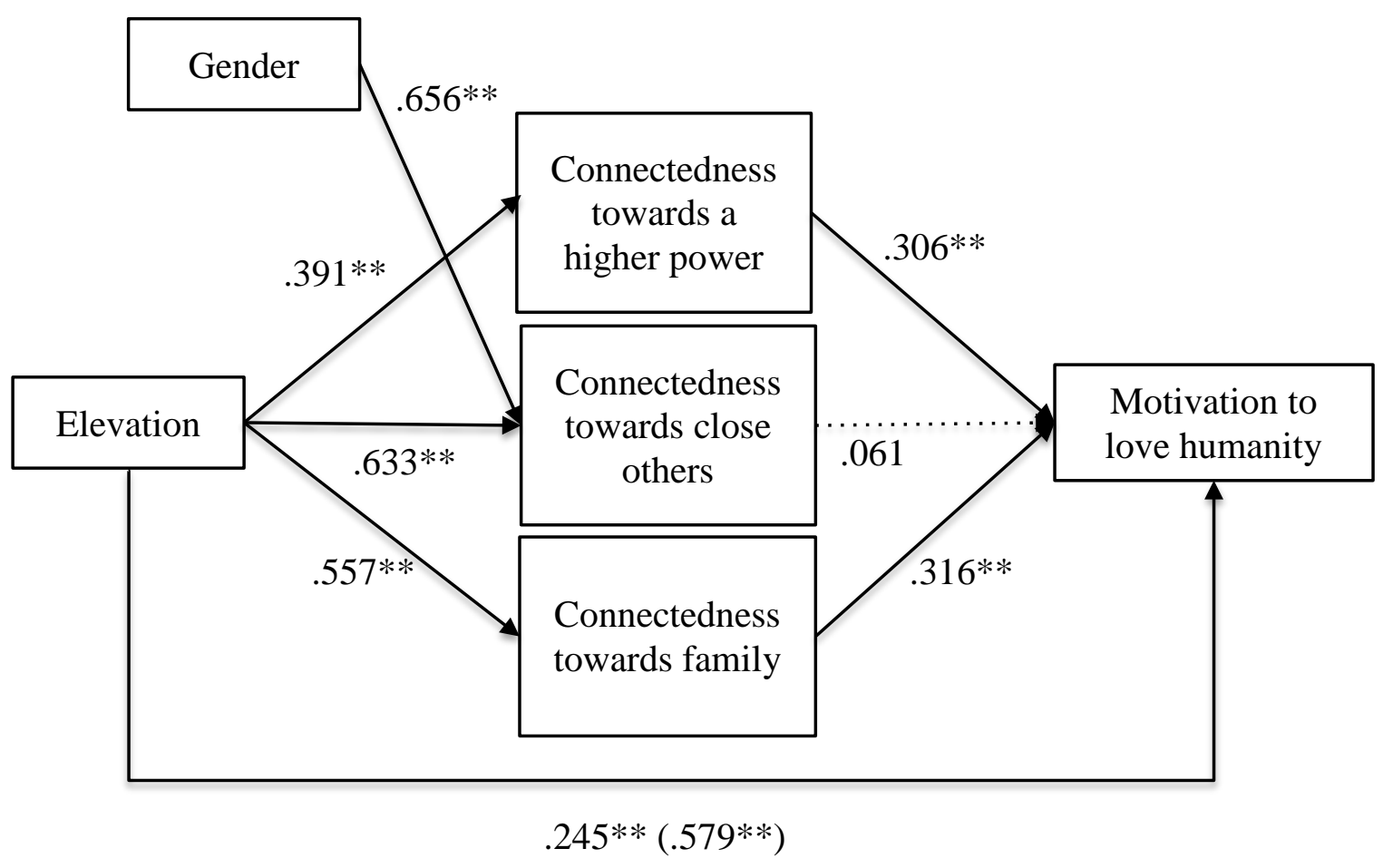

Note: Unstandardized coefficients are reported. The covariate condition was not significant in the model. Parameter in parenthesis represents the total effect.

Figure 2. Results of the mediation analysis for Hypothesis 5. 